ORIGINAL ARTICLE

\title{
Arbuscular mycorrhizal fungi associated with the babassu palm (Attalea speciosa) in the eastern periphery of Amazonia, Brazil
}

\author{
Camila Pinheiro NOBRE ${ }^{1 *}$, Marlon Gomes da COSTA², Bruno Tomio GOTO ${ }^{3}$, Christoph GEHRING ${ }^{1}$ \\ Universidade Estadual do Maranhão - UEMA, Programa de Pós Graduação em Agroecologia - PPGA, Campus Paulo VI, Tirirical, CEP 65055-310, São Luís, MA, Brasil \\ 2 Instituto Federal do Maranhão - IFMA, Campus São Raimundo das Mangabeiras, BR-230, km-319 (Antiga Fazenda Paraíso), CEP 65840-000, São Raimundo das \\ Mangabeiras, MA, Brasil \\ 3 Universidade Federal do Rio Grande do Norte - UFRN, Departamento de Botânica, Ecologia e Zoologia - DBEZ, Campus Universitário Lagoa Nova, CEP 59072-970, \\ Natal, RN, Brasil \\ * Corresponding author: camilaenobre@yahoo.com.br
}

\begin{abstract}
Babassu, Attalea speciosa (Arecaceae) is a ruderal palm native to Amazonia, which turned dominant in frequently burned lands throughout the 'arc of deforestation' and other degraded lands, in extreme cases attaining complete dominance. This study investigated arbuscular mycorrhizal fungi (AMF) as one possible explanation for the outstanding ecological success of this exceptional palm. We explored the relationships between the babassu palm and native arbuscular mycorrhizal fungi and babassu effects on the AMF richness and mycorrhizal inoculum potential (MIP) in the eastern periphery of Amazonia. For this purpose, we sampled topsoil $(0-20 \mathrm{~cm})$ at the onset of the rainy season from a 5-year-old secondary forest regrowth (SEC) area with three levels of babassu dominance (sites with 10, 50 and $70 \%$ babassu biomass shares), and at three distances $(0,2.5$ and $4 \mathrm{~m})$ from isolated babassu patches within a degraded pasture (PAS), both with five replications per treatment. Glomerospore density varied from 100 to 302 per gram of soil, 56\% higher in SEC than PAS. We identified a total of 16 AMF species, with dominance of Acaulospora (six species) followed by Glomus (three species). AMF richness increased with babassu dominance in SEC sites, and reduced with distance from babassu patches within the PAS. The colonization rate of babassu roots was higher in SEC than in PAS, whereas MIP was similar in both areas and without treatment differences. Our study points to strong mycorrhizal association of the babassu palm as a potential mechanism for its outstanding ecological success in degraded lands.
\end{abstract}

KEYWORDS: Glomeromycota; species richness; humid tropics; degraded lands

\section{Fungos micorrízicos arbusculares associados com a palmeira babaçu (Attalea speciosa) na periferia leste da Amazônia, Brasil}

\section{RESUMO}

Babaçu, Attalea speciosa (Arecaceae) é uma palmeira ruderal nativa da Amazônia, dominante em terras frequentemente queimadas ao longo do "arco de desmatamento" e outras áreas degradadas, em casos extremos atingindo domínio completo. Este estudo investigou os fungos micorrízicos arbusculares (FMA) como possível explicação do sucesso ecológico desta palmeira. Nós exploramos as relaçóes entre o babaçu e glomerosporos, efeitos do babaçu na riqueza destes fungos e o potencial do inóculo micorrízico (PIM) na periferia oriental da Amazônia. Amostras de solo $(0-20 \mathrm{~cm})$ foram coletadas no início da estação chuvosa em uma área de floresta secundária (SEC) de cinco anos de idade e três níveis de dominância do babaçu (10, 50 e $70 \%$ de biomassa de babaçu) e a três distâncias (0; 2,5 e $4 \mathrm{~m}$ ) de 'ilhas' de babaçu isoladas em uma pastagem degradada (PAS), ambas com cinco repetiçóes por tratamento. A densidade de esporos de FMA variou de 100 a 302 por grama de solo, sendo 56\% maior em SEC do que em PAS. Dezesseis espécies de FMA foram identificadas, com predominância de Acaulospora (seis espécies) seguidos do gênero Glomus (três espécies). A riqueza destes fungos aumentou com o domínio da palmeira em SEC e reduziu com a distância das 'ilhas' de babaçu em PAS. A taxa de colonização das raízes de babaçu foi superior nas áreas de SEC enquanto o PIM não apresentou diferenças entre os tratamentos. Nosso estudo aponta a uma forte associaçáo micorrhízica da palmeira babaçu, um possível mecanismo central no seu sucesso ecológico em áreas degradadas.

PALAVRAS-CHAVE: Glomeromycota, riqueza de espécies, trópico úmido, áreas degradadas 


\section{INTRODUCTION}

The babassu palm, Attalea speciosa Mart (Arecaceae) occurs on an estimated 17 million hectares throughout Amazonian Brazil, Bolivia and the Guianas (Teixeira and Carvalho 2007). The genetic diversity of babassu is highest in a region called 'Cocais', in the northern Brazilian states of Piauí and Maranhão (SantoFilho et al. 2013). Though occurring in low densities in mature rainforests, this ruderal palm has turned dominant with human exploration, especially throughout the eastern and southern peripheries of Amazonia known as the 'arc of deforestation', but increasingly also in the northern periphery and in patches in central Amazonia (Teixeira and Carvalho 2007).

A key adaptive trait of babassu is its excellent adaptation to frequent burns and to shifting cultivation cycles. The dormancy of babassu nuts is interrupted by burning, vegetative resprouting of juvenile palms is vigorous, and the apical meristem is $0.5-1 \mathrm{~m}$ belowground (Sousa et al. 2016), but to date nothing is known on possible relationships between babassu and soil organisms, notably arbuscular mycorrhizal fungi (AMF).

AMF are abundant and ubiquitous organisms in all environments and can form mutualistic associations with an estimated $74 \%$ of all plant species of the planet (Smith and Read 2008; van der Heijden et al. 2015). The principal role of AMF consists in supplying immobile nutrients and water to the host plants in exchange for photosynthates, though they also can help protect the host plant from other abiotic and from biotic stress (Smith and Read 2008).

Mycorrhizal symbiosis can specially benefit palms as these typically have lignified roots with few root hairs (Bouamri et al. 2014), thus aiding in accessing low-availability soil nutrients and soil water. Despite their key ecological importance, there are few records of the occurrence of AMF species in Amazonia (Peña-Venega et al. 2007; Nobre et al. 2010; Stürmer and Siqueira 2011). Nothing to date is known on the possible association between the ruderal babassu palm and AMF.

We hypothesized that babassu palms establish an association with AMF, affecting glomerospore abundance and mycorrhizal infection potential, shaping AMF species composition in their surroundings, and that this association is a key factor for the ecological success of babassu in degraded lands. We explored the relationship between babassu and AMF by assessing glomerospore density and species composition, babassu root infection, and AMF inoculum potential in two environments in the eastern periphery of Amazonia: a secondary forest fallow regrowth with differing degrees of babassu dominance, and a pasture with differing distances from isolated babassu palm patches.

\section{MATERIAL AND METHODS}

\section{Study area}

The study was carried out in the surroundings of Mato Grosso community (241'S, 44¹6'W), on São Luís Island (a continental island), in Maranhão state, Brazil (Figure 1). The climate of the region is classified according to Köppen as sub-humid equatorial $A w$, with annual precipitation of about $2000 \mathrm{~mm}$ concentrated in a seven-month rainy season. The soil type was classified as yellow latosol (Latossolo Amarelo) according to Embrapa (2006).

\section{Sampling}

We collected 0-20 cm topsoil samples as composite samples of four subsamples per sampling point at the onset of the rainy season (January 2008) in an area of secondary forest fallow regrowth (SEC), and an area of spontaneous (nonplanted) pasture (PAS) with isolated babassu palm patches. All sites were level $\left(<2^{\circ}\right.$ inclination $)$ and sampling avoided boarder zones.

In the 5-year-old secondary forest area (SEC) we selected three sites with spontaneous fallow vegetation after slash and burn shifting cultivation. The sites had (as far as known) the same preceding land-use history and similar soil texture (sandy loam), but differed in the dominance of babassu palms (approximately 10\%, 50\% and 70\% biomass shares of total aboveground biomass). In each of the three secondary forest sites (approximately 2.5 hectares each) we randomly sampled five points (as composite samples of four cores each).

The pasture site (PAS) was degraded due to annual fires, and had been without grazing for the last five months preceding sampling. The pasture was a homogenous mixture of spontaneously occurring grasses and herbs (i.e., not a planted pasture), and contained isolated patches of babassu, composed by an adult palm surrounded by young (stemless) palms. We selected five such babassu patches separated from one another by distances $>100 \mathrm{~m}$, and sampled soil at $0 \mathrm{~m}$ (i.e., within the patch), $2.5 \mathrm{~m}$ and $4 \mathrm{~m}$ distance from the patch, as composite

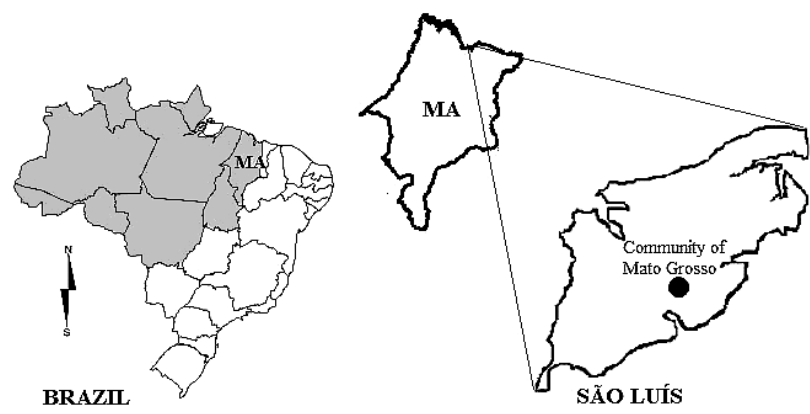

Figure 1. Map of Brazil highlighting the legal Amazon region (in gray), Maranhão state, and the location of Mato Grosso community on São Luís Island, where the study sites were located. 
samples of the four orthogonal directions from each adult palm (the patch center).

Composite soil samples (one per treatment) were analyzed in the soil chemistry laboratory of Maranháo State University, following routines ( $\mathrm{pH}$ and carbon, phosphorus, potassium, calcium, magnesium, sodium, aluminum, potential acidity $(\mathrm{H}+\mathrm{Al})$ availability) described in Embrapa (1997) (Table 1).

\section{Glomerospore analysis}

Glomerospores were extracted from 100g of homogenized and air-dried soil by wet sieving followed by sucrose centrifugation (Gerdemann and Nicolson 1963; Jenkins 1964) and quantified (number of glomerospores per $100 \mathrm{~g}$ of soil $=$ glomerospore abundance) using a stereomicroscope (40x). We subsequently dispersed glomerospores on microscope slides with PVLG (polyvinyl alcohol and lactoglycerol) and PVLG + Melzer's reagent $(1: 1, v / v)$. We identified species following the manual of Schenck and Perez (1990), as well as by consulting the international culture collection of arbuscular mycorrhizal fungi database (INVAM) (http://invam.caf.wvu.edu) and the on-line AMF collection of the Department of Plant Pathology, University of Agriculture in Szczecin, Poland (http://www.agro. ar.szczecin.pl/ $\sim$ jblaszkowski/). We adopted the classification proposed by Oehl et al. (2011), including taxa described by Goto et al. (2012) and Błaszkowski and Chwat (2013).

\section{Colonization rate}

From each soil sample we separated 100 fine $(\leq 2 \mathrm{~mm})$ babassu root segments. The characteristic red color allowed for unambiguous selection of roots from the babassu palm, but for the same reason it was necessary to perform a bleaching process with alkaline solution of hydrogen peroxide $\left(\mathrm{H}_{2} \mathrm{O}_{2}\right)$ for 20 minutes. We subsequently stained the samples with trypan blue (Koske and Gemma 1989) and visually estimated the percentage of mycorrhizal colonization of babassu fine roots via the grid intersect method following procedures by Giovanetti and Mosse (1980).

Table 1. Chemical characterization of $0-20 \mathrm{~cm}$ topsoil sampled in two environments in the eastern Brazilian Amazon: secondary forest sites differing in babassu dominance and in a degraded pasture at different distances from isolated babassu palm patches (one composite sample for each treatment).

\begin{tabular}{|c|c|c|c|c|c|c|c|c|c|}
\hline & $\mathrm{pH}$ & $\mathrm{P}^{1}$ & $K^{1}$ & $\mathrm{Ca}^{2}$ & $\mathrm{Mg}^{2}$ & $\mathrm{Na}^{1}$ & $\mathrm{Al}$ & $\mathrm{H}+\mathrm{Al}$ & $\mathrm{C}^{3}$ \\
\hline & $\mathrm{CaCl}_{2}$ & $\mathrm{mgdm}^{-3}$ & \multicolumn{6}{|c|}{-------mmol $\mathrm{dm}^{-3}-\mathrm{s}^{-}$} & $\mathrm{g} \mathrm{kg}^{-1}$ \\
\hline \multicolumn{10}{|c|}{ Babassu dominance (\%) } \\
\hline 10 & 5.1 & 4.0 & 0.4 & 20 & 8.0 & 0.8 & 0 & 34 & 20.1 \\
\hline 50 & 4.7 & 4.0 & 0.6 & 10 & 11.0 & 1.0 & 0 & 21 & 18.1 \\
\hline 70 & 4.4 & 2.8 & 0.5 & 19 & 9.0 & 1.0 & 0 & 33 & 16.5 \\
\hline \multicolumn{10}{|c|}{ Distance from babassu (m) } \\
\hline 0 & 4.4 & 12 & 0.5 & 7.0 & 6.0 & 0.8 & 2.0 & 40 & 14.6 \\
\hline 2.5 & 4.2 & 13 & 0.4 & 7.0 & 5.0 & 0.8 & 1.0 & 36 & 12.6 \\
\hline 4 & 4.7 & 11 & 0.3 & 5.0 & 4.0 & 0.5 & 2.0 & 36 & 12.1 \\
\hline
\end{tabular}

${ }^{1}$ Mehlich $1,{ }^{2} 1 \mathrm{M} \mathrm{KCl},{ }^{3}$ Walkey \& Black digestion

\section{Mycorrhizal inoculum potential (MIP)}

Mycorrhizal inoculum potential refers to the ability of AMF structures in the soil (glomerospores, as well as fragments of hyphae and of colonized roots) to form a mycorrhizal association with plant species (Rubin and Stürmer 2015). This method gives a relative estimate of the ability of mycorrhizal fungi to infect new plant symbionts (Wolfe et al. 2007) though it does not indicate which propagules were responsible for this colonization.

We estimated MIP in each soil sample using sorghum (Sorghum bicolor L) as trap plant in $500 \mathrm{~mL}$ vases, and following recommendations of Brundret (1991). After 40 days we completely harvested shoots of the trap plants and determined shoot and root dry biomass and foliar phosphoruscontent following standard procedures described in Tedesco et al. (1995). We estimated the sorghum root mycorrhizal colonization rate according to Koske and Gemma (1989) and Giovanetti and Mosse (1980).

\section{Statistical analysis}

We checked our data for normality visually with histograms and using Kolmogorov-Smirnov and Lilliefor's tests, and for homogeneity of variance using the Cochran and Bartlett tests. We separately compared the impacts of babassu dominance in secondary forests and of distances from babassu patches within the degraded pasture via ANOVA and post-hoc Tukey test for glomerospore abundance and babassu colonization rate. We performed a principal components analysis (PCA), using $\mathrm{R}$ package vegan, for pattern recognition and the evaluation of associations between variables (soil parameters, glomerospore abundance and babassu root colonization rate), and the influence of the treatments (SEC and PAS) on these relationships. We used nonmetric multidimensional scaling (NMDS) based on Euclidean distances for MIP (sorghum shoot dry mass, sorghum root dry mass, colonization rate of sorghum roots and foliar P-content) to analyze the behavior pattern of the variables. The analysis was carried out with the R package factoextra. We generated graphics with ggplot2 (Wickham 2009; Oksanen et al. 2013; Kasambara and Mundt 2017).

\section{RESULTS}

\section{Glomerospore abundance and babassu root colonization}

Glomerospore abundance ranged from 100 to 302 per 100 grams of soil and was approximately twice as high in SEC sites as in PAS sites (Table 2). Both babassu dominance in SEC and distance from babassu patches in PAS significantly affected glomerospore abundance. In SEC, glomerospore abundance was maximum at $50 \%$ babassu dominance. In PAS glomerospore abundance declined with distance from the babassu patches. 
Table 2. Glomerospore abundance and babassu root colonization rate in two environments in the eastern Brazilian Amazon: secondary forest (SEC) sites with differing degrees of babassu dominance, and degraded pasture sites (PAS) at differing distances from babassu patches. Values are means $\pm \mathrm{SE}$; letters refer to statistically significant groupings within SEC and within PAS (according to the Tukey HSD post hoc test) and statistical difference between SEC and PAS (according to a t-test). See Material and Methods for treatment definitions.

\begin{tabular}{lcc}
\hline & Glomerospores per $100 \mathrm{~g}$ soil & Babassu root colonization rate (\%) \\
\hline \multicolumn{2}{l}{ Babassu dominance (\%) } \\
\hline 10 & $221 \pm 13 \mathrm{~b}$ & $45.2 \pm 2.71 \mathrm{~b}$ \\
\hline 50 & $302 \pm 20 \mathrm{a}$ & $49.6 \pm 2.54 \mathrm{a}$ \\
\hline 70 & $219 \pm 36 \mathrm{~b}$ & $43.5 \pm 3.15 \mathrm{~b}$ \\
\hline Distance from babassu (m) & $43.9 \pm 2.87 \mathrm{a}$ \\
\hline 0 & $170 \pm 18 \mathrm{a}$ & $43.0 \pm 4.69 \mathrm{a}$ \\
\hline 2.5 & $148 \pm 9 \mathrm{ab}$ & $34.2 \pm 2.22 \mathrm{~b}$ \\
\hline 4 & $100 \pm 12 \mathrm{~b}$ & \\
\hline Overall values per environment & $46.08 \pm 0.46 \mathrm{a}$ \\
\hline SEC & $247 \pm 4 \mathrm{a}$ & $40.36 \pm 0.59 \mathrm{~b}$ \\
\hline
\end{tabular}

The colonization rate of babassu roots ranged from $34.2 \%$ to $49.6 \%$, being higher in SEC than in PAS (Table 2). Both glomerospore abundance and babassu root colonization rate were maximum at $50 \%$ babassu dominance in SEC, and decreased with distance to the babassu patches in PAS.

\section{AMF species richness}

We recorded the occurrence of a total of 16 AMF species, distributed in seven genera (Table 3). The genus Acaulospora was the most species rich (6), followed by Glomus (3) and seven other genera with one species each. Nine AMF species occurred exclusively in SEC sites, whereas four occurred only in PAS. The highest number of AMF species (nine) was recorded in SEC sites with 10\% babassu dominance. The number of AMF species ranged between three and four at SEC sites with higher babassu dominance, and at all distances from babassu patches in PAS.

\section{Mycorrhizal inoculum potential}

Mean shoot dry biomass of sorghum trap plants ranged from $0.18 \mathrm{~g}$ to $0.47 \mathrm{~g}$, and was, on average, $57 \%$ lower in SEC than in PAS (Table 4). In PAS, sorghum shoot biomass was

Table 3. Occurrence of arbuscular mycorrhizal fungi (AMF) species in two environments in the eastern Brazilian Amazon: secondary forest (SEC) sites with differing degrees of babassu dominance, and degraded pasture (PAS) at differing distances from babassu patches. See Material and Methods for treatment definitions.

\begin{tabular}{|c|c|c|c|c|c|c|c|}
\hline \multirow{2}{*}{ AMF species } & \multicolumn{3}{|c|}{ Babassu dominance (\%) } & \multicolumn{3}{|c|}{ Distance from babassu (m) } & \multirow{2}{*}{$\begin{array}{l}\text { Life - histor } \\
\text { strategy' }\end{array}$} \\
\hline & 10 & 50 & 70 & 0 & 2.5 & 4 & \\
\hline \multicolumn{8}{|l|}{ Acaulosporaceae } \\
\hline Acaulospora denticulata Sieverd. \& S. Toro & - & - & - & $x$ & $x$ & $x$ & * \\
\hline Acaulospora excavata Ingleby \& C. Walker & - & - & $x$ & - & - & - & * \\
\hline Acaulospora foveata Trappe \& Janos & - & - & - & - & - & $x$ & * \\
\hline Acaulospora morrowie Spain \& N.C. Schenck & $x$ & - & - & - & - & - & * \\
\hline Acaulospora rehmii Sieverd. \& S. Toro & $x$ & - & - & - & - & - & * \\
\hline Acaulospora scrobiculata Trappe & $x$ & - & $x$ & - & - & - & * \\
\hline \multicolumn{8}{|l|}{ Entrophosporaceae } \\
\hline Entrophospora infrequens (I.R. Hall) R.N. Ames \& R.W. Schneid. & - & - & - & $x$ & - & - & * \\
\hline \multicolumn{8}{|l|}{ Glomeraceae } \\
\hline Funneliformis halonatum (S.L. Rose \& Trappe) Oehl, G.A. Silva \& Sieverd. & $x$ & - & - & - & - & - & $r$ \\
\hline Glomus sp1 Tul. \& Tul. & $x$ & $x$ & - & - & $x$ & $x$ & $r$ \\
\hline Glomus sp2 Tul. \& Tul. & $x$ & $x$ & - & - & - & & r \\
\hline Glomus sp3 Tul. \& Tul. & - & $x$ & - & - & - & - & $r$ \\
\hline Sclerocystis sinuosa Gerd. \& B.K. Bakshi & - & - & $x$ & $x$ & - & - & * \\
\hline \multicolumn{8}{|l|}{ Dentiscutataceae } \\
\hline Fuscutata heterograma Oehl, F.A. de Souza, L.C. Maia \& Sieverd. & - & - & - & - & $x$ & $x$ & K \\
\hline \multicolumn{8}{|l|}{ Racocetraceae } \\
\hline $\begin{array}{l}\text { Cetraspora pellucida (T.H. Nicolson \& N.C. Schenck) Oehl, F.A. de Souza } \\
\text { \& Sieverd. }\end{array}$ & $x$ & - & - & - & - & - & K \\
\hline \multicolumn{8}{|l|}{ Scutellosporaceae } \\
\hline $\begin{array}{l}\text { Orbispora pernambucana (Oehl, D.K. Silva, N. Freitas, L.C. Maia) Oehl, } \\
\text { G.A.Silva \& D.K. Silva }\end{array}$ & $x$ & $x$ & - & - & $x$ & - & K \\
\hline Scutellospora calospora (T.H. Nicolson \& Gerd.) C. Walker \& F.E. Sanders & $x$ & - & - & - & - & - & K \\
\hline N species per treatment & 9 & 4 & 3 & 3 & 4 & 4 & \\
\hline $\mathrm{N}$ species per environment & & 12 & & & 7 & & \\
\hline
\end{tabular}


significantly higher from topsoil samples taken at $0 \mathrm{~m}$ and $2.5 \mathrm{~m}$, than at $4 \mathrm{~m}$ from the babassu patch centers, suggesting elevated soil fertility within the babassu patches. The sorghum root mycorrhizal colonization rate (ranging from $43.8 \%$ to 50.7\%), and foliar P-content (ranging from 0.318 to 1.198 $\mathrm{g} \mathrm{kg}$-1) did not vary significantly with babassu dominance in SEC, nor with distance from babassu patches in PAS.

The principal components analysis (PCA) depicted a clear separation between SEC and PAS sites, as well as systematic differences along babassu influence gradients (both the

Table 4. Mycorrhizal infection potential (MIP) with sorghum as trap plant in soil from two environments in the eastern Brazilian Amazon: secondary forest fallow regrowth sites with different babassu dominance, and pasture at different distances from babassu patches. Values are the mean \pm SE of shoot dry biomass (SDB), percentage of mycorrhizal colonization (\% col) and foliar P-content (in $\mathrm{kg}^{-1}$ ). See Material and Methods for treatment definitions.. Letters indicate significant distance-related differences in SDB within the pasture according to ANOVA and Tukey HSD. All other comparisons were non-significant

\begin{tabular}{|c|c|c|c|}
\hline & SDB (g) & $\% \mathrm{col}$ & $P\left(\mathrm{~g} \mathrm{~kg}^{-1}\right)$ \\
\hline \multicolumn{4}{|c|}{ Babassu dominance (\%) } \\
\hline 10 & $0.182 \pm 0.015$ & $50.52 \pm 1.569$ & $1.198 \pm 0.001$ \\
\hline 50 & $0.256 \pm 0.004$ & $46.91 \pm 1.115$ & $0.442 \pm 0.000$ \\
\hline 70 & $0.214 \pm 0.016$ & $50.73 \pm 0.797$ & $0.691 \pm 0.001$ \\
\hline \multicolumn{4}{|c|}{ Distance from babassu (m) } \\
\hline 0 & $0.446 \pm 0.006 a$ & $43.77 \pm 0.786$ & $0.652 \pm 0.000$ \\
\hline 2.5 & $0.392 \pm 0.020 a b$ & $48.06 \pm 0.428$ & $0.318 \pm 0.001$ \\
\hline 4 & $0.308 \pm 0.009 b$ & $43.99 \pm 1.076$ & $0.956 \pm 0.002$ \\
\hline
\end{tabular}

dominance gradient of babassu in SEC and the distance gradient from babassu patches in PAS) (Figure 2). PCA explained 79.6\% of the total data variance $(59.1 \%$ in the first axis and $20.5 \%$ in the second axis), being mostly influenced by soil $\mathrm{pH}$, soil acidity and P-availability. In SEC, samples in 10\% and 50\% babassu dominance areas were related to glomerospore abundance, babassu root colonization rate, and $\mathrm{K}$ and $\mathrm{Mg}$ availability, whereas samples in $70 \%$ dominance area were highly related with $\mathrm{pH}$ levels. In PAS, the samples closer to babassu (0 and $2.5 \mathrm{~m}$ ) were related with phosphorus-contents.

NMDS ordination scores of MIP parameters tended to separate samples from SEC and PAS (Figure 3). Within SEC the samples from the $10 \%$ babassu dominance site tended to group separately from those from 50\% and 70\% dominance sites. The samples from PAS tended to form a more homogeneous group, independently of distance from babassu patches.

\section{DISCUSSION}

Total glomerospore abundances found in this study were lower than those reported for mycorrhizal associations of Desmoncus orthacanthos Mart. in Mexico (400 to 3200 glomerospores per $100 \mathrm{~g}$ of soil) (Ramos-Zapata et al. 2006), and in a coconut plantation in Kerala, India (214 to 299 glomerospores per 50g of soil) (Rajeshkumar et al. 2015), higher than in a peach-palm (Bactris gasipaes Kunth) rhizosphere in the Amazon (27 to 48 glomerospores in $50 \mathrm{~g}$ of soil) (Silva Júnior

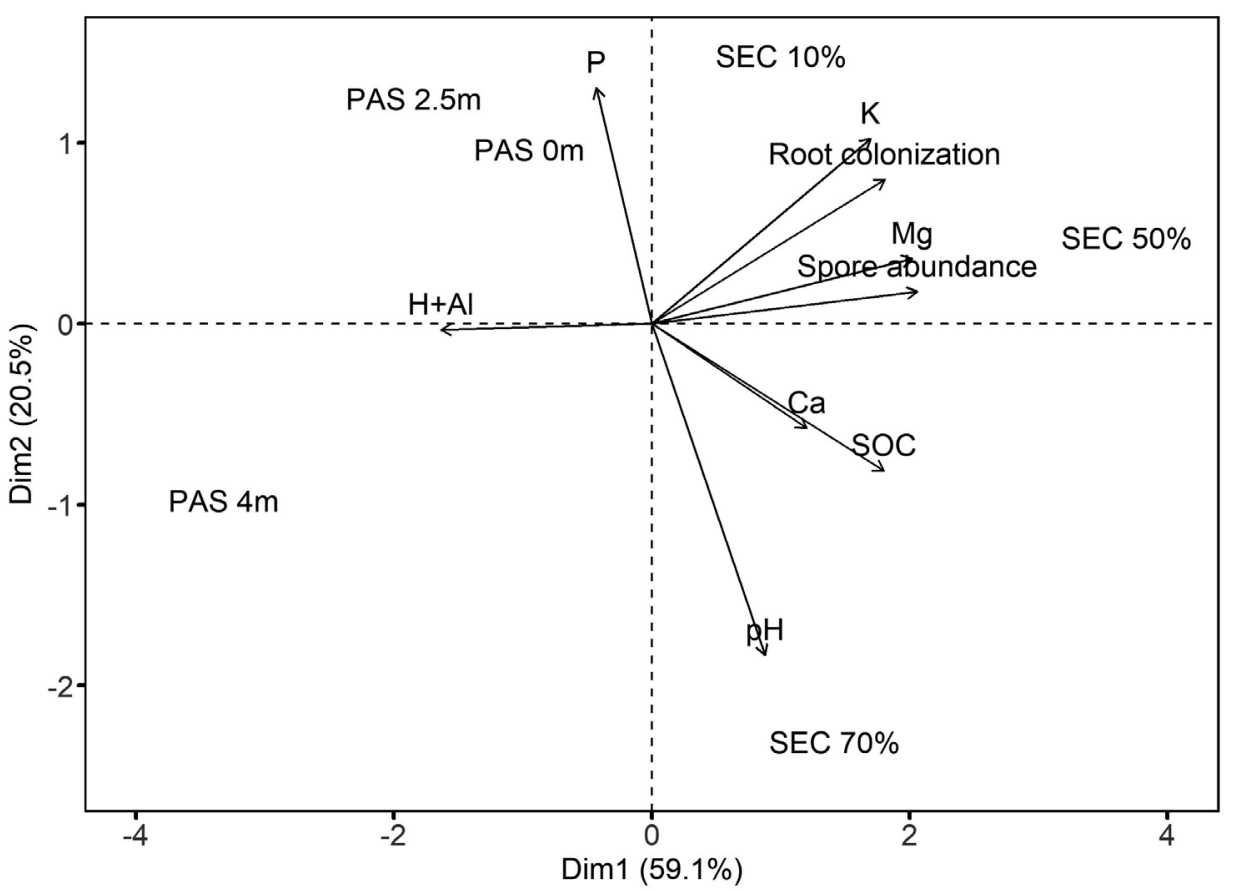

Figure 2. Principal component analysis (PCA) for seven chemical soil variables and two mycorrhizal parameters in soil samples from secondary forest regrowth sites with different degrees of babassu palm dominance (SEC 10\%, SEC 50\%, SEC 70\%) and from degraded pasture sites at different distances from isolated babassu patches (PAS $0 \mathrm{~m}$, PAS $2.5 \mathrm{~m}$, PAS $4 \mathrm{~m}$ ). Spore abundance = glomerospores abundance per $100 \mathrm{~g}$ soil; Root colonization = babassu root mycorrhizal infection rate. 


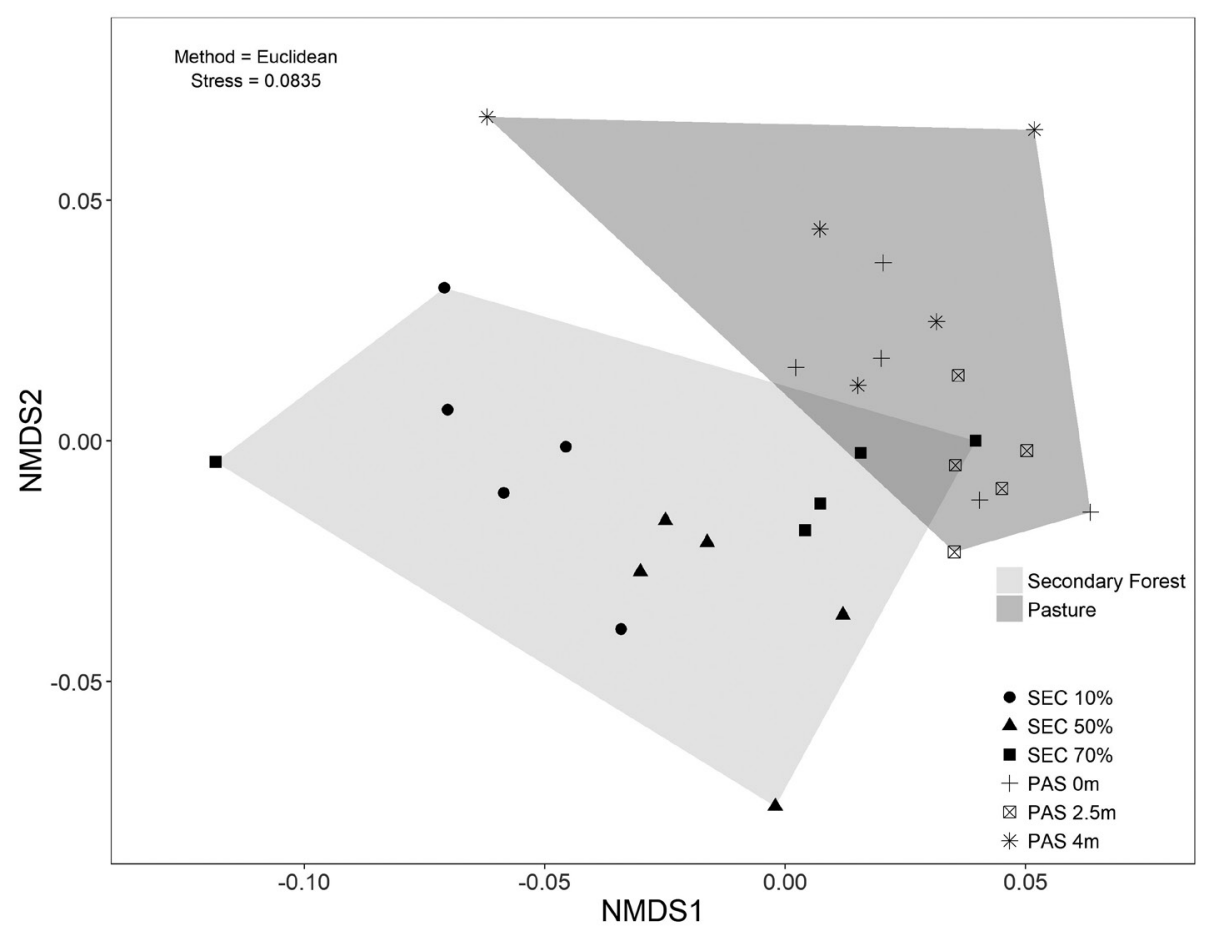

Figure 3. Nonmetric multidimensional scaling of MIP parameters (sorghum shoot dry biomass, foliar phosphorus-content and root colonization rate) in secondary forest sites with differing babassu dominance (SEC10\%, SEC50\% and SEC70\%) and in a pasture at differing distances (PAS $0 \mathrm{~m}$, PAS $2.5 \mathrm{~m}$, PAS $4 \mathrm{~m}$ ) from isolated babassu patches.

and Cardoso 2006), and similar to those found in an alley cropping system located $20 \mathrm{~km}$ from our study site (148 to 335 glomerospores in $100 \mathrm{~g}$ of soil) (Nobre et al. 2010). Our values for mycorrhizal colonization rates of babassu roots and MIP were in line with values reported for a peach-palm culture in the Amazon (13.54 - 43.95\%) (Silva Júnior and Cardoso 2006) and coconut plantations in India (32.33 - 55.17\%) (Rajeshkumar et al. 2015). Our MIP values were also similar to those reported by Nobre et al. (2010) in a legume alleycropping system (51 to 54\%). Similar values for inoculum potential were also found in areas of secondary vegetation in the Atlantic Forest ( $49 \%$ to $58 \%$ ) (Zangaro et al. 2012).

We found a similar number of species than Nobre et al. (2010) in a legume alley cropping system located at $20 \mathrm{~km}$ from our study, yet there were only five species in common between both studies, resulting in 27 AMF species listed for the state of Maranhão. Other studies in the Amazon region listed 18 AMF species in mature rainforests, secondary regrowth and pastures in the Colombian Amazon (РeñaVenegas et al. 2007), and 61 species in mature rainforests, differently-aged secondary regrowth, agroforestry systems, crops and pastures in the western Brazilian Amazon (Stürmer and Siqueira 2011).

Glomus and Acaulospora are the most common and species-rich AMF genera, both in natural and in humantransformed environments, being able to adapt to a wide range of environmental conditions (Jefwa et al. 2012; Pereira et al. 2014). Contrary to most studies, we found Acaulospora rather than Glomus as the predominant genus, in accordance with Leal et al. (2009) for the western Amazon. Acaulospora species are known to be specially successful in very acidic soils (Teixeira-Rios et al., 2013, Pereira et al., 2014), as is the case in our study sites. The predominant Acaulospora species in our study (A. scrobiculata in SEC, and A. foveata in PAS) have been recorded in Atlantic rainforest fragments (Trufem et al. 1994; Silva et al. 2006). Acaulospora denticulata, which was very common in PAS, was recorded in tropical pastures and forests (Bever et al. 1996; Uhulmann et al. 2004).

Glomerospore production and AMF root colonization are affected by soil characteristics and management type (Pereira $e t$ al. 2014), soil acidity (Hazard et al.2013), salt stress (Bencherif et al. 2015), water stress (Cartmill et al. 2008), pesticide use (Tu 1992), and heavy metals (Tahat and Sijam 2012). Our results indicate that vegetation type, babassu dominance and distance from babassu patches can affect glomerospore production. The reduction of glomerospore density with distance from babassu patches was in accordance with (Nobre et al. 2010), who observed a decrease in glomerospores with increasing distance from trees in an alley-cropping system,

Arbuscular mycorrhiza fungi are believed to be host generalists (Válvy et al. 2016), which may explain the remarcable similarity of AMF species composition in our study site. A notable exception was Scleroystis sinuosa, which occurred exclusively in SEC at highest babassu dominance, 
and in PAS within the babassu patches, suggesting that this species may indeed be a babassu-host specialist. This species is thus recommended for future more systematic bioprospection studies. On the other hand, host plants are believed to influence other associated microbiota in their surroundings to their own benefit via specific root exudates (Haichar et al. 2014; van Nuland et al. 2016).

Host plants differ widely in their degree of mycorrhizal association (both regarding root colonization and carbon investment) (Afek et al. 1990; Angelini et al. 2012). Plant species with thick roots and few root hairs likely will benefit most from mycorrhizal associations (van der Heijden $e t$ al. 2015). Palms typically have relatively thick and partly lignified 'fine roots' (van der Heijden 2003; van der Heijden et al.2015), which explains the strong association of babassu with AMF we found in both the SEC and PAS sites. The higher biomass of sorghum grown in soils from within the PAS babassu patches also indicates that babassu impacts its surroundings. Positive plant-soil feedbacks (sensu van der Putten et al. 2013 and Revillini et al. 2016) could enable the babassu palm to create a particularly advantageous environment for itself. Above-average biomass shares of babassu fine and mid-sized (up to $5 \mathrm{~mm}$ diameter) roots throughout 1-meter soil profiles were recorded less than 10 $\mathrm{km}$ from our study sites (Sousa et al. 2016), further supporting the idea that the heavy below-ground investment of babassu is a key element in the outstanding ecological success of this ruderal palm throughout degraded Amazonian lands.

\section{CONCLUSIONS}

This was the first study to evaluate the relationship of babassu with arbuscular mycorrhizal fungi. Whereas babassu effects on AMF species composition were weak, glomerospore density and root colonization were strongly affected by babassu presence and abundance, pointing to a high level of mycorrhizal association. Above-average belowground babassu investment both in AMF and in its root system could be at the heart of the outstanding ecological success of this ruderal palm and should be considered for an ecoefficient babassu palm management in degraded Amazonian agroecosystems.

\section{ACKNOWLEDGMENTS}

To the Conselho Nacional de Desenvolvimento Científico e Tecnológico - CNPq for financial support, and to Universidade Estadual do Maranhão - UEMA for the scholarship of the first author.

\section{REFERENCES}

Afek, U.; Rinaldelli, E.; Menge, J.A.; Johnson, E.L.V.; Pond, E. 1990. Mycorrhizal inoculum influence colonization of cotton, onion and pepper seedlings. Journal of the American Society for Horticultural Science 115: 938-942.
Angelini, G.A.R.; Loss, A.; Pereira, M.G.; Torres, J.L.R.; Saggin Júnior, O.J. 2012. Colonização micorrízica, densidade de esporos e diversidade de fungos micorrízicos arbusculares em solo de Cerrado sob plantio direto e convencional. Semina: Ciências Agrarias, 33: 115-130.

Bencherif, K.; Boutekrabt, A.; Fontaine, J.; Laruelle, F.; Dalpè, Y.; Sahraoui, A.L.H. 2015. Impact of soil salinity on arbuscular mycorrhizal fungi biodiversity and microflora biomass associated with Tamarix articulata Vahll rhizosphere in arid and semi-arid Algerian areas. Science of the Total Environment, 533: 488-494.

Bever, J.D.; Morton, J.B.; Antonovics, J.; Schultz, P.A. 1996. Host-dependent sporulation and species diversity of arbuscular mycorrhizal fungi in a mown grassland. Journal of Ecology, 84: 71-82.

Błaszkowski, J.; Chwat, G. 2013. Septoglomus deserticola emended and new combinations in the emended definition of the family Diversisporaceae. Acta Mycology, 48: 89-103.

Bouamri, R.; Dalpé, Y.; Serrhini, M.N. 2014. Effect of seasonal variation on arbuscular mycorrhizal fungi associated with date palm. Emirates Journal of Food and Agriculture, 26: 977-986.

Brundrett, M.C. 1991. Mycorrhizas in natural ecossystems. Advances in Ecological Research, 21: 171-313.

Cartmill, A.D.; Valdez-Aguilar, L.A.; Bryan, D.L.; Alarco'n A. 2008. Arbuscular mycorrhizal fungi enhance tolerance of vinca tohigh alkalinity in irrigation water. Scientia Horticulturae, 115: 275-284.

EMBRAPA. 1997. Manual de métodos de análise de solo. 2nd. ed. Centro Nacional de Pesquisa de Solos, Rio de Janeiro, 212p.

EMBRAPA. 2006. Sistema brasileiro de classificação de solos. Centro Nacional de Pesquisa de Solos, Rio de Janeiro, 306p.

Gerdemann, J.W.; Nicolson, T.H. 1963. Glomerospores of mycorrhizal Endogone species extracted from soil by wet sieving and decanting. Transactions of the British Mycological Society, 46: 235-244.

Giovannetti, M.; Mosse, B. 1980. An evaluation of techniques for measuring vesicular arbuscular mycorrhizal infection in roots. New Phytologist, 84: 489-500.

Goto, B.T.; Silva, G.A.; Assis, D.M.A.; Silva, D.K.A.; Souza, R.G.; Ferreira, A.C.A.; et al. 2012. Intraornatosporaceae (Gigasporales), a new family with two new genera and two new species. Mycotaxon, 119:117-132.

Haichar, F.Z.; Santaella, C.; Heulin, T.; Achouak, W. 2014. Root exudates mediated interactions belowground. Soil Biology and Biochemistry, 77: 69-80.

Hazard, C.; Gosling, P.; van der Gast, C.; Mitchell, D.T.; Doohan, F.M.; Bending, G.D. 2013. The role of local environment and geographical distance in determining community composition of arbuscular mycorrhizal fungi at the landscape scale. The ISME Journal, 7: 498-508.

Jefwa, J.M.; Okoth, S.; Achira, P.; Karanja, N.; Kahindi,J.; Nijuguini, S.; et al. 2012. Impact of land use types and farming practices on occurrence of arbuscular mycorrhizal fungi (AMF) 
Taita-Taveta district in Kenya. Agriculture, Ecosystems and Environment, 157: 32-39.

Jenkins, W.R. 1964. A rapid centrifugal-flotation technique for separating nematodes from oil. Plant Disease Reporter, 48: 692.

Kassambara, A.; Mundt, F. 2017. factoextra: Extract and visualize the results of multivariate data analyses. R package version 1.0.4. (https://CRAN.R-project.org/package=factoextra). Accessed on 10/11/2017.

Koske, R.E.; Gemma, J.N. 1989. A modified procedure for staining roots to detect VA mycorrhizas. Mycological Research, 92: 486-488.

Leal, P.L.; Stürmer, S.L.; Siqueira, J.O. 2009. Occurrence and diversity of arbuscular mycorrhizal fungi in trap cultures from soils under different land use systems in the Amazon, Brazil. Brazilian Journal of Microbiology, 40: 111-121.

Nobre, C.P.; Ferraz Júnior, A.S.L.; Goto, B.T.; Berbara, R.L.L.; Nogueira, M.D.C. 2010. Fungos micorrízicos arbusculares em sistema de aléias no Estado do Maranhão, Brasil. Acta Amazonica, 40: 641-646.

Oehl, F., Sieverding, E., Palenzuela, J., Ineichen, K., Silva, G.A. 2011. Advances in Glomeromycota taxonomy and classification. IMA Fungus, 2: 191-199.

Oksanen, J; Blanchet, F.G.; Friendly, M.; Kindt, R.; Legendre, P.; McGlinn, D.; et al.. 2017. vegan: Community Ecology Package. R package version 2.4-3. (https://CRAN.R-project. org/package=vegan). Accessed on 10/10/2017.

Peña-Venegas, C.P.; Cardona, G.I.; Arguelles, J.H.; Arcos, A. L. 2007. Micorrizas arbusculares del sur de la Amazonia colombianay su relación con algunos factores fisicoquímicos y biológicos del suelo. Acta Amazonica, 37: 327-336.

Pereira, C.M.R.; Silva, D.K.A.; Ferreira, A.C.A.; Goto, B.T.; Maia, L.C. 2014. Diversity of arbuscular mycorrhizal fungi in Atlantic forest areas under different land uses. Agriculture, Ecosystems and Environment, 185: 245-252.

Rajeshkumar, P.P.; Thomas, G.V.; Gupta, A.; Gopal, M. 2015. Diversity, richness and degree of colonization of arbuscular mycorrhizal fungi in coconut cultivated along with intercrops in high productive zone of Kerala, India. Symbiosis, 65: 125-141.

Ramos-Zapata, J.A.; Orellana, R.; Allen, E.B. 2006. Establishment of Desmoncus orthacanthos Martius (Arecaceae): effect of inoculation with arbuscular mycorrhizae. Revista de Biologia Tropical, 54: 65-72.

Revillin, D.; Gehring, C.A.; Johnson, N.C. 2016. The role of locally adapted mycorrhizas and rhizobacteria in plant-soil feedback systems. Functional Ecology, 30: 1086-1098.

Rubin, J.G.K.R.; Stürmer, S.L. 2015. Potencial de inóculo micorrízico e importância do comprimento do micélio para a agregaçấo de solos de ambiente fluvial. Revista Brasileira de Ciência do Solo, 39: 59-68.

Santos-Filho, F.S.; Almeida Júnior, E.B.; Soares, C.J.R.S. 2013. Cocais Zona ecotonal natural ou artificial? Revista Equador (UFPI), 1: 2 -13.

Schenck, N.C.; Perez, Y. 1990. Manual for the Identification of VA Mycorrhizal Fungi, 3rd. ed. Synergistic Publications, Gainesville. 286p.
Silva, C.F.; Pereira, M.G.; Silva, E.M.R.; Correia, M.E.F.; SagginJúnior, O.J., 2006. Fungos micorrízicos arbusculares em áreas no entorno do Parque Estadual da Serra do Mar e Ubatuba (SP). Revista Caatinga, 19: 1-10

Silva, I.R.; Mello, C.M.A.; Ferreira Neto, R.A.; Silva, D.K.A.; Melo, A.L.; Oehl, F., Maia, L.C. 2014. Diversity of arbuscular mycorrhizal fungi along an environmental gradient in the Brazilian semiarid. Applied Soil Ecology, 84: 166-175.

Smith, S.E.; Read, D.J. 2008. Mycorrhizal Symbiosis, 3rd. ed. Academic Press, New York, 800p.

Sousa, J.T.R.; Moraes, F.H.R.; Gehring, C. 2016. Root biomass in a shifting cultivation system in the eastern periphery of Amazonia, and contribution of the babassu palm. Agroforestry Systems, 90: 351- 360 .

Stürmer, S.L.; Siqueira, J.O. 2011. Species richness and glomerosporess abundance of arbuscularmycorrhizal fungi across distinct land uses in western Brazilian Amazon. Mycorrhiza, 21: 255-67.

Tahat, M.M.; Sijam, K. 2012. Mycorrhizal fungi and abiotic environmental conditions relationship. Research Journal of Environmental Sciences, 6: 125-133.

Tedesco, J.M.; Gianello, C.; Bissani, C.A.; Bohnem, H.; Volkweiss, S.J. 1995. Análise de solo, plantas e outros materiais. 2nd. ed. Universidade Federal do Rio Grande do Sul, Porto Alegre, 174p.

Teixeira, M.A.; Carvalho, M.G. 2007. Regulatory mechanism for biomass renewable energy in Brazil, a case study of the Brazilian babassu oil extraction industry. Energy, 32: 999-1005.

Teixeira-Rios, T.; Souza, R.G. de; Maia, L.C.; Oehl, F.; Lima, C.E.P. 2013. Arbuscular mycorrhizal fungi in a semi-arid, limestone mining-impacted area of Brazil. Acta Botanica Brasilica, 27: 688-693.

Trufem, S.F.B.; Malatinszky, S.M.M.; Otomo, H.S. 1994. Fungos micorrízicos arbusculares em rizosferas de plantas do litoral arenoso do Parque estadual da Ilha do Cardoso, SP, Brasil. Acta Botanica Brasilica, 8: 219-229.

Tu, C.M. 1992. Effects of some herbicides on activities of microorganisms and enzymes in soil. Journal of Environmental Science and Health, 27: 695-709.

Uhlmann, E.; Görke,C.; Peterson,A.; Oberwinkler,F. 2004. Comparison of species diversity of arbuscular mycorrhizal fungi in winter-rainfall areas of South Africa and summer-rainfall areas of Namibia. Mycological Progress, 3: 267-274.

Válvy, K.; Mardhiah, U.; Rillig, M.C.; Hempel, S. 2016. Community assembly and coexistence in communities of arbuscular mycorrhizal fungi. The ISME Journal, 10: 2341-2351.

van der Heijden, M.G.; Martin, F.M.; Selosse, M.A.; Sanders, I.R. 2015. Mycorrhizal ecology and evolution: the past, the present, and the future. New Phytologist, 205: 1406-1423.

van der Heijden, M.G.A. 2002. Arbuscular mycorrhizal fungi as a determinant of plant diversity: in search of underlying mechanisms and general principles. In: van der Heijden, M.G.A; Sanders, I.A. (Ed.). Mycorrhizal Ecology (Ecological Studies). v. 137, 1st. ed. Springer, Heidelberg, p.243-261.

van der Putten, W.H.; Bardgett, R.D.; Bever, J.D.; Bezemer, T.M.;Casper, B.B.; Fukam, T. et al. 2013. Plant-soil feedbacks: 
the past, the present and future challenges. Journal of Ecology, 101: 265-276.

van Nuland, M.E.; Wooliver, R.C.; Pfennigwerth, A.A.; Read, Q.D.; Ware, I.M.; Mueller, L.; Fordyyce, J.A.; Schweitzer, J.A.; Bailey, J.K. 2016. Plant-soil feedbacks: connecting ecosystem ecology and evolution. Functional Ecology, 30: 1032-1042.

Wickham, H. 2009. ggplot2: Elegant Graphics for Data Analysis. Springer Verlag, New York, 260p.

Wolfe, B.E.; Mummey, D.L.; Rillig, M.C.; Klironomos, J.N. 2007. Small-scale spatial heterogeneity of arbuscular mycorrhizal fungal abundance and community composition in a wetland plant community. Mycorrhiza, 17: 175-183.
Zangaro, W.; Ansanelo, A.P.; Lescano, L.E.A.M.; Alves, R.A.; Rondina, A.B.L.; Nogueira, M.A. 2012. Infection intensity, glomerospores density and inoculum potential of arbuscular mycorrhizal fungi decrease during secondary succession in tropical Brazilian ecosystems. Journal of Tropical Ecology, 28: 453-462.

RECEIVED: 08/01/2018

ACCEPTED: 05/08/2018

ASSOCIATE EDITOR: Oscar Valverde 